\title{
E-learning Content Design using ADDIE and SECI: Case of Shelving Activity in Research Organization
}

\author{
Dyah Kusumastuti $^{\mathrm{a}, 1}$, Rayinda Pramuditya Soesanto ${ }^{\mathrm{a}, 2}$, Amelia Kurniawati ${ }^{\mathrm{a}, 3}$, Mochamad Teguh \\ Kurniawan ${ }^{\mathrm{a}, 4}$ \\ ${ }^{a}$ School of Industrial Engineering, Telkom University, Bandung,40257, Indonesia \\ E-mail: ${ }^{1}$ dyahkusumastuti.09@gmail.com; ${ }^{2}$ raysoesanto@telkomuniversity.ac.id; ${ }^{3}$ ameliakurniawati@telkomuniversity.ac.id; \\ ${ }^{4}$ teguhkurniawan@telkomuniversity.ac.id
}

\begin{abstract}
Knowledge sharing considered an important role in an organization, especially in an organization that focused on research activity such as research organization. Research Organization is an organization that focused on providing scientific information in various forms of collection. The collection often used as a reference for many researchers. The collection saved in the organization library service section and displayed by the types and classified to ease the finding process. In the shelving process, some employees take a different way to do the process besides the shelving procedure and gain new knowledge through experience from it in the form of knowledge. The problem occurred when the turnover of the employee is high because of the job role rotation. It is needed a way to preserve the experience from the previous employee of the shelving process, so when rotation occurred, the learning time of new employees can be reduced. E-learning is one of the solutions that can help the learning process. ADDIE is used as the model for the content of e-learning. The purpose of this research is to design the e-learning content for the shelving process by converting previous tacit knowledge using the SECI method. The output of this paper is the best practice for shelving activity that is used as the content of e-Learning. This research contribution can give a reference on how to convert tacit knowledge into e-learning. Future research can be done to develop the present application by evaluating the weakness and enhancing the feature for improvement.
\end{abstract}

Keywords - ADDIE; content development; knowledge conversion; shelving; SECI.

\section{INTRODUCTION}

In the era of Industry 4.0, the transformation not only affects the production process but also in the learning process. The need for innovative and flexible learning, which is accessible, is considered as important [1]. Knowledge is an important asset for the company; the form of knowledge can be seen as a document, idea, experience, etc. People as an asset are considered important factors to gain a competitive advantage [2]. Knowledge lies within the people because it often hard to articulate. The variation of knowledge that lies within people can have a different result because there is a difference between the experience of each people.

Knowledge needs to be documented formally so other people can absorb knowledge. According to Agisni et al. [3], knowledge can be divided into two types, which is tacit and explicit knowledge. Explicit knowledge is defined as the knowledge that is easy to articulate and in the form of formal and systematic language. Tacit knowledge is defined as the knowledge within the people that forge through experience in the form of the mental model.
Knowledge sharing considered an important role in an organization, especially in an organization that is focused on research activities such as research organization. Research Organization is an organization that focused on providing scientific information in various forms of collection. The collection often used as a reference for many researchers. $\mathrm{R}$ is one of the state-owned research organizations that provides all-access to scientific information for research purposes. The access is divided into two categories, which are limited and unlimited. The library is provided by the organization to help the researcher gain access to information.

The library service unit runs the library. The unit is responsible for giving library access. According to Piriyadharshini and Dorairajan [4], the challenge of today's library is the ability to anticipate and respond to changes and handling the advancement of technological changing. One activity that is the activity of the unit is shelving. The collection saved in the organization library service section and displayed by the types and classified to ease the finding process is called shelving [5]. The shelving process in $\mathrm{R}$ organization is divided into three periods, which are daily, monthly, and yearly. 
The primary purpose of the shelving process is to arrange all library collections based on collection type and rack number. Shelving can affect satisfaction because it takes time to find and search for documents. The problem occurred because the shelving process is not good. By interviewing the stakeholder, it is known that the problem happened because of the high turnover in the organization. The organization has the policy to rotate the employee once a year; this causes the employee to learn a new position within the organization, the downfall from this policy is that it usually takes time for the employee to settle with the new position.

It is needed a way to preserve the experience from the previous employee of the shelving process, so when rotation occurred, the learning time of new employees can be reduced. E-learning is a process to deliver instruction and content into a digital device to help people learn the content [6]. Usually, e-learning consists of example, practice, and feedback to promote the learning process. E-learning is one of the solutions that can help the learning process because it can help the engagement of people in learning, and as the acceleration of expertise through different scenarios. The organization often using e-learning to save learning time, because, in an organization, time is essential. Since the tacit knowledge is hard to formalize, it is needed to direct sharing working experiences [7]. By using e-learning, it helps a new employee to accelerate their learning process before continuing with the direct experience. Self-regulated learning can improve the technical competencies of the individual [8]. Therefore e-learning is considered as important. E-learning can help the organization to provide interaction anytime and anywhere to contribute to the learning process [9].

In company $\mathrm{R}$, the staff that is tasked for the shelving process is just only one; with the high turnover in the organization, the tacit knowledge that lies within the shelving staff needed to be converted into a more formal way. SECI Method (Socialization, Externalization, Combination, and Internalization) that is developed by Nonaka and Takeuchi [10] can be the solution to gain knowledge from the staff. The SECI method converts the tacit knowledge into new tacit knowledge by combining it with another new knowledge [3].

The purpose of this research is to design the content of the shelving process by using the SECI Method. SECI is used as a tool to gain knowledge, and after the knowledge is gain, the e-learning content is design using ADDIE. A lot of research uses ADDIE as a development method for elearning. Previous research from Utama et al. [11] focused on designing e-learning for preventive maintenance in manufacture. Research by Komninou [12] focused on the development of the content of e-learning using ADDIE for social network learning. Patel et al. [13] focused on the development of e-learning for the health treatment program.

\section{MATERIAL AND METHOD}

This research purpose is to design the content of the shelving process by extracting the knowledge and experience from the staff based on knowledge conversion using the SECI method. The respondent from this research is the current staff for the shelving process and the manager.
The result of this research is the best practices of the shelving process that is used as a material in designing eLearning content and the design of e-Learning content. The e-learning content is developed using the ADDIE method. According to Mayfield [14], ADDIE is a framework useful for examining, creating, and implementing development and learning programs. Garbani-Nerini, Nadzeya, and Lorenzo [15] stated that ADDIE is a five-phase model to create educational, instructive, and training tools and materials. Figure 1 shows the ADDIE method.

In the analysis phase, specific goals target is set; this phase must answer what skills, knowledge, and abilities that the learner must gain when using e-learning. This phase contains clear guideline guidelines on what is needed and possible for the content. When some learning goals cannot be met, new resources must be secured, or learning goals must be altered.

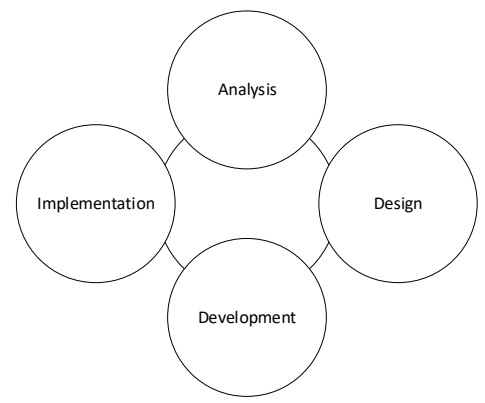

Fig. 1 ADDIE Model

After the requirement is gained, the next step is to design the content of e-learning. The design phase is used to determine whether learning objectives meet the learning goals. In the design phase, the SECI method is used to extract the knowledge from the expert by converting the tacit knowledge from the expert into an explicit one by combining it with the new knowledge. SECI model describes four phases of converting knowledge which is socialization, externalization, combination, and internalization. Figure 2 shows the SECI Model.

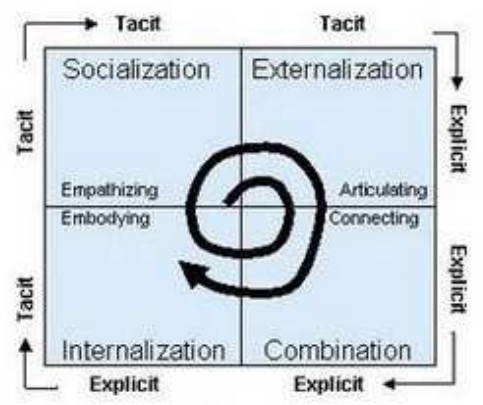

Fig. 2 SECI Model

According to Nonaka and Takeuchi [5], Socialization is defined as the sharing process and creation of tacit knowledge by observation; usually, the interview is conducted to gain tacit knowledge. Externalization is defined as a transformation of tacit knowledge into explicit knowledge through dialogue and reflection, often, the output of this stage is a documented knowledge such as recording, procedure, etc. The combination is defined as the conversion process of explicit knowledge into new explicit knowledge through synthesizing. Internalization is defined as a learning 
process and knowledge acquisition by organization members towards explicit knowledge that spread across the organization through self-experience.

In the development phase, the creation of the content is conduct. The content involves the overall learning framework, such as the infrastructure, exercises, lectures, simulations, and other training material. After the content is developed, the next step is to implement the content through e-learning. The implementation phase is conducted by testing the content to the user, which is the staff that is responsible for the shelving process. Blackbox testing is used in the testing to gain better insight into the content. After the implementation phase, the next step is evaluation. In this final phase, all aspects such as learning goal achievement, training efficiency, technical problems that hinder learning, and any new learning opportunities are assessed.

\section{RESULT AND DISCUSSION}

\section{A. Analysis}

In the analysis phase, it is needed to identify the needs of the e-Learning. The first step is to identify the existing business process in the organization. From the interview with the chief of library service, the shelving activity is done daily through the experience of the staff and without work procedure, this is because the learning process in the organization is done individually by each employee, in the recent year there is only one necessary guidance about shelving, but the book excludes the technique in the shelving process.

The identification of needs of the e-learning content is made by interviewing the staff who oversee shelving. In the interview process, two big questions are asked, which is the existing learning process and the desired one. Table I shows the interview result.

TABLE I

INTERVIEW RESULT

\begin{tabular}{|l|l|l|}
\hline No. & \multicolumn{1}{|c|}{ Interview Result } & \multicolumn{1}{c|}{ Requirement } \\
\hline 1 & $\begin{array}{l}\text { There is no standardization in } \\
\text { the shelving process }\end{array}$ & $\begin{array}{l}\text { It is needed standardization } \\
\text { in shelving activity. }\end{array}$ \\
\hline 2 & $\begin{array}{l}\text { Every person in the unit use their } \\
\text { method for the shelving process }\end{array}$ & \\
\hline 3 & $\begin{array}{l}\text { Current guidance only covers the } \\
\text { essential aspect like a job } \\
\text { description but excludes the } \\
\text { technique for shelving. }\end{array}$ & $\begin{array}{l}\text { It is needed new learning } \\
\text { media }\end{array}$ \\
\hline
\end{tabular}

From Table I, it is known that the existing condition in the organization is based on experience, and there is a different approach for the shelving activity conducted by each staff. Table II shows the identification result of user needs for the e-learning content. The identification process is done as guidance and a basic step in designing the content to meet the desired objective from the requirements.

The identification of the user needs to be gained the expected result from the user, that is the staff of the shelving process. From the result, it is known that e-learning must accommodate assessment for the user to know the level of knowledge of each user that accessed the e-learning. The language and choice of words in the content must be considered.
TABLE II

REQUIREMENT RESULT

\begin{tabular}{|c|c|c|}
\hline No. & Interview Result & Requirement \\
\hline 1 & $\begin{array}{l}\text { e-learning must not } \\
\text { contain full text only }\end{array}$ & e-learning contain text and picture \\
\hline 2 & $\begin{array}{l}\text { e-learning is full of } \\
\text { content material }\end{array}$ & e-learning has desired material \\
\hline 3 & The text is easy to read & $\begin{array}{l}\text { e-learning display is clear and easy to } \\
\text { read }\end{array}$ \\
\hline 4 & $\begin{array}{l}\text { Word is easy to } \\
\text { understand }\end{array}$ & e-learning word is easy to understand \\
\hline 5 & There is exercise & $\begin{array}{l}\text { e-learning can assess the user } \\
\text { knowledge level }\end{array}$ \\
\hline
\end{tabular}

The combination of picture and text is desired because from the interview; it is known that id the media is only contained text, the user tends to abandoned the e-learning. Figure 3 shows the learning scheme process.

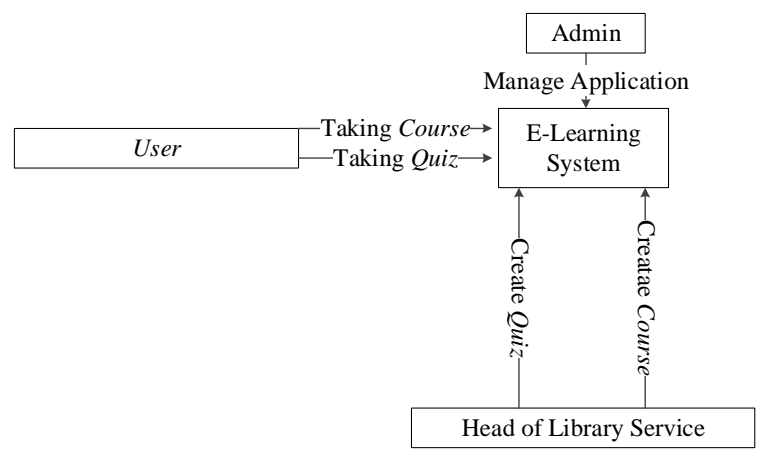

Fig. 3 Learning Scheme

From figure 3, It is known that the learning scheme consists of admin, user and the head of the library service. The learning scheme for the user only for taking courses and quiz. Head of Library Service is given the task to create a quiz and course. Admin is given the task to manage the eLearning system. The requirement for the e-learning application needs a learning management system such as Moodle for the application, the basic hardware requirement for application is Hard Disk minimum of 100GB, processor minimum of $2.4 \mathrm{GHz}$ and minimum RAM of $1 \mathrm{~GB}$. For software requirements, it is needed a web browser that supports HTML5 and Flash. Moodle is a web-based application, with the designated requirement, e-learning can be accessed through a web browser.

\section{B. Design}

The design phase is the next step for the development of the content of e-learning. In this phase material and concept for e-learning are created. The design process is done through the knowledge conversion process using SECI. In the socialization phase, data gathering is conducted and the conversion process of tacit knowledge from the interviewee. Figure 4 shows the socialization phase scheme.

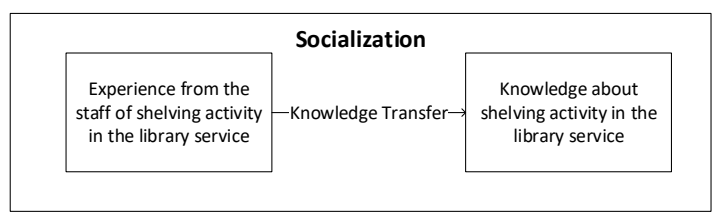

Fig. 4 Socialization Phase Scheme 
The library service unit in the organization has 17 staff; in this research, only two staff choose as a respondent. The reason for the decision is that the head of the library service recommends the two staff because they are experienced enough and have a long history in shelving activity. The tacit knowledge from the two respondents may have the same level, but the experience in the shelving activity may differ. The data collection process is done through observation in the shelving activity. Observation is conducted by exploring the activity and asked the respondent how to do the activity. In the socialization phase, exploration is conducted with the other data that support the knowledge conversion process. The purpose of the action is to identify the tacit and explicit knowledge within the shelving activity. Table III shows the example of the socialization phase output.

TABLE III

SOCIALIZATION PHASE OUTPUT RESULT

\begin{tabular}{|l|l|l|l|l|}
\hline \multicolumn{1}{|c|}{ Activity } & \multicolumn{1}{c|}{$\begin{array}{c}\text { Detail } \\
\text { Activity }\end{array}$} & \multicolumn{1}{|c|}{ Input } & Output & $\begin{array}{c}\text { Key } \\
\text { Performer }\end{array}$ \\
\hline $\begin{array}{l}\text { Identification } \\
\text { of tacit and } \\
\text { explicit } \\
\text { knowledge }\end{array}$ & $\begin{array}{l}\text { Direct } \\
\text { observation } \\
\text { to gain the } \\
\text { desired } \\
\text { knowledge }\end{array}$ & $\begin{array}{l}\text { e-learning } \\
\text { contain text } \\
\text { and picture }\end{array}$ & $\begin{array}{l}\text { Observation } \\
\text { protocol }\end{array}$ & $\begin{array}{l}\text { The staff of } \\
\text { shelving } \\
\text { activity }\end{array}$ \\
\hline
\end{tabular}

The externalization phase is started with the design of the business process of shelving activity. Figure 5 shows the externalization phase scheme.

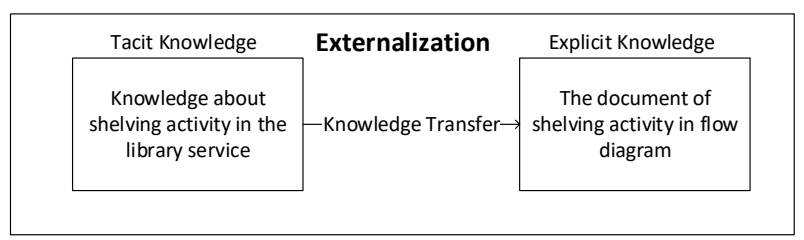

Fig. 5 Externalization Phase Scheme

The designated business process source is from the result of the tacit knowledge gathered in the previous phase. The business process is designed in the flow diagram. After the documentation process is done, the next step is to summarize the availability of tacit and explicit knowledge in every activity. In the combination phase, the previous result from the externalization phase is combined to gain the best practice of the shelving activity. Brainstorming is used to gather data. Figure 6 shows the combination process scheme.

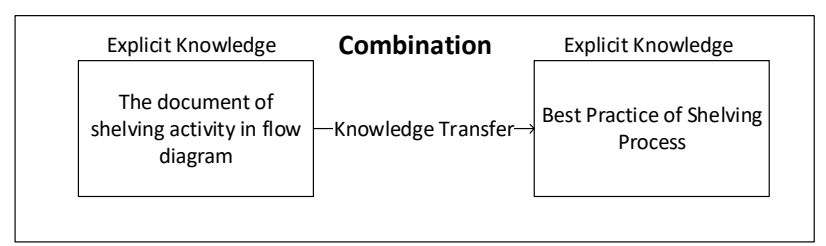

Fig. 6 Combination Phase Scheme

To determine the best practice for shelving activity, two important factors need to be considered. The first one is the time to acquire the collection, and the second one is the effectivity of shelving activity. Table IV shows an example of the combination phase. The best practice is selected based on the consensus of the two staff through focus group discussion if the two staff feels that one of the business processes is better than the others than that business process is selected. When the staff is no consensus about the best practice, the business process will be combined form their perspective.

TABLE IV

COMBINATION PHASE EXAMPLE

\begin{tabular}{|l|l|l|l|}
\hline No. & \multicolumn{1}{|c|}{ Staff A } & \multicolumn{1}{c|}{ Staff B } & \multicolumn{1}{c|}{ Best Practice } \\
\hline 1 & $\begin{array}{l}\text { Check library } \\
\text { condition }\end{array}$ & $\begin{array}{l}\text { Check library } \\
\text { condition }\end{array}$ & $\begin{array}{l}\text { Check library } \\
\text { condition }\end{array}$ \\
\hline 2 & $\begin{array}{l}\text { Collect the } \\
\text { collection }\end{array}$ & Collect the collection & $\begin{array}{l}\text { Collect the } \\
\text { collection }\end{array}$ \\
\hline 3 & $\begin{array}{l}\text { Bring the } \\
\text { collection to the } \\
\text { main desk }\end{array}$ & $\begin{array}{l}\text { Read the classification } \\
\text { number }\end{array}$ & $\begin{array}{l}\text { Bring the } \\
\text { collection to the } \\
\text { main desk }\end{array}$ \\
\hline
\end{tabular}

The internalization phase objective is to share the combined knowledge with other staff. In the internalization phase, the result from the combination phase then transferred into e-learning. The e-learning development process is adjusted with the knowledge gained from the conversion process. Figure 7 shows the internalization process. Based on the result of the previous phase, the best practice of shelving units in the organization is created. The best practice is one of the new explicit knowledge that will be transferred into tacit knowledge for others.

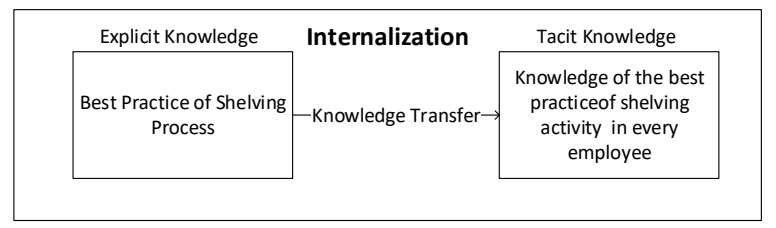

Fig. 7 Internalization Phase Scheme

\section{Development}

The development process is the step in ADDIE for developing the content of e-learning. The input of this step is the result of the combination phase in SECI, which is the best practice of shelving activity. The best practice document is formed into content for e-learning. The elearning is design to give easy access to knowledge transfer of employees in the library service unit. To design the content of e-learning it is needed a storyboard. The storyboard can give a big picture of the content. The elearning that is designed consists of three main modules which are the shelving process module, quiz module, and archiving module.

In the shelving process module, two main topics are delivered which are the best practice and the animation tutorial. The tutorial consists of an explanation of the detailed steps about how to do the shelving process. The content is delivered using adobe flash. Figure 8 shows the tutorial content.

The animation tutorial explains what must be done in the shelving process with tacit and explicit knowledge in each step. The content of this section is consists of the picture for each step in the shelving process and gives visualization to make it easier for the learning process and knowledge transfer. 


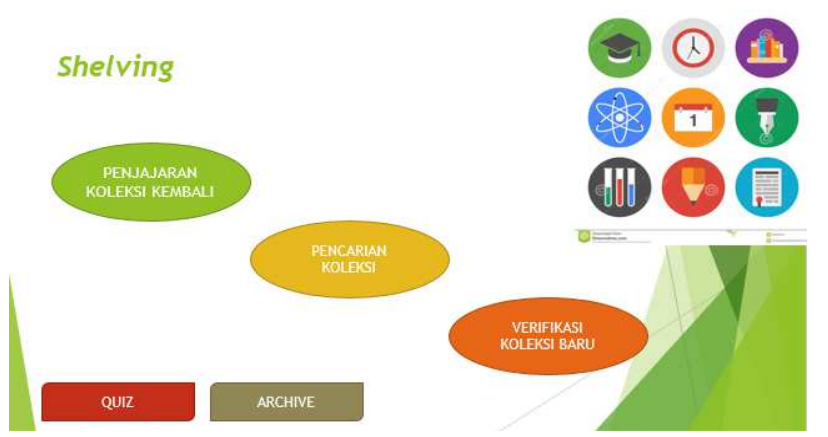

Fig. 8 e-Learning Content Example (1)

The animation tutorial explains what must be done in the shelving process with tacit and explicit knowledge in each step. The content of this section is consists of the picture for each step in the shelving process and gives visualization to make it easier for the learning process and knowledge transfer.

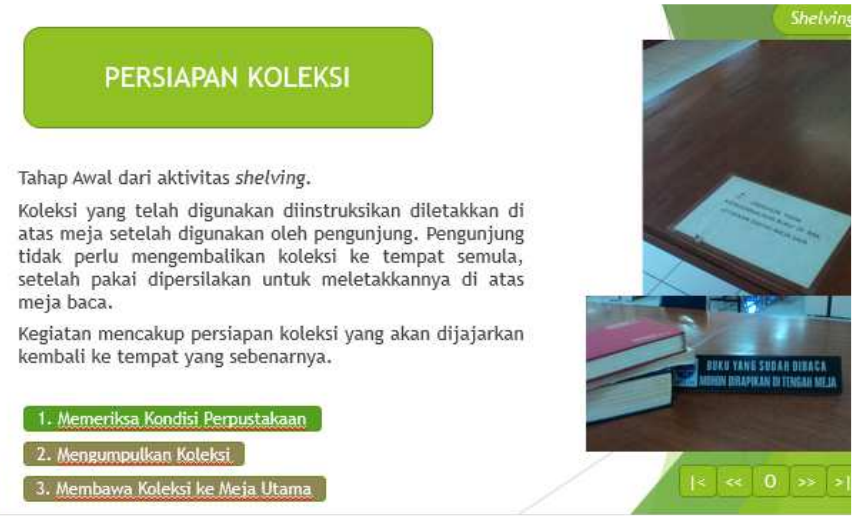

Fig. 9 e-Learning Content Example (2)

Figure 9 shows an example of e-learning content for collection preparation. To give a better understanding of the user, e-learning is embedded in the quiz module. The quiz module consists of two types, which are multiple-choice and true or false. The module is designed to give a better understanding of the knowledge of the user. The quiz module provides a question that is focused on the shelving process. In True and False, the user must choose whether the statement is true or false. The question is set to be randomized, so the user is not trying to remember the sequence of the answer. The archive module is designed as file storage that can be easily accessed to help the user for learning the process.

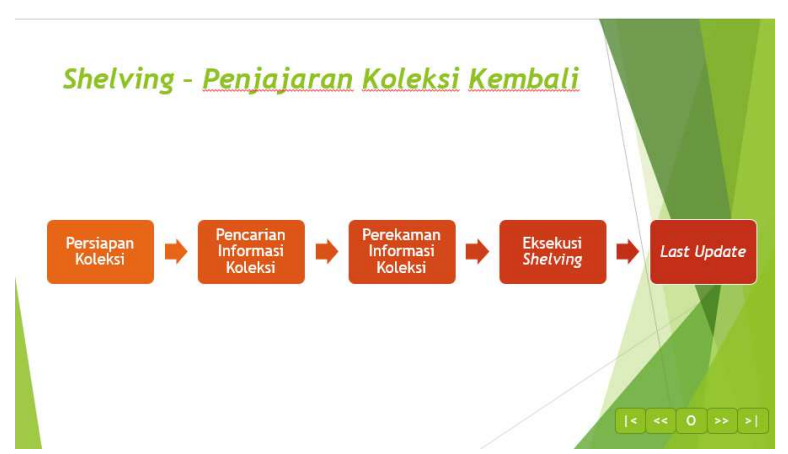

Fig. 10 Shelving process step in the e-learning

\section{Implementation}

The implementation phase focused on testing the content; the created e-learning is tested to the user. The test is done by giving the simulation of the e-learning operation to the staff. The implementation plan will provide a big picture of what needs to be done by the organization before implementing the e-learning and its content. Figure 11 shows the implementation of the roadmap. From the figure to create the best environment of e-Learning success, the first step is to provide the organization with sufficient infrastructure. After the infrastructure is set, the next step is to train the employee about the e-learning application so the employee will be ready to implement the e-learning for their daily activity.

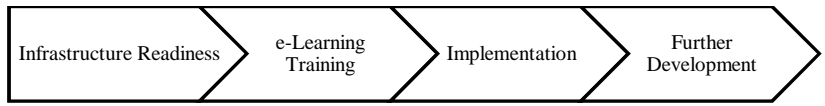

Fig. 11 Implementation Roadmap

Table $\mathrm{V}$ shows the implementation time projection of elearning. The infrastructure preparation will take five days because to make the e-learning online; it only needs a PC and an internet connection. The longer time of infrastructure preparation is in the installation and configuration. The training of the e-learning will only take three days full; the training will consist of the necessary use for e-learning and customization. The implementation will take place when there is a new staff for the shelving process when there is a rotation. Further development of e-learning will take approximately 9 months to develop.

TABLE V

IMPLEMENTATION TIME

\begin{tabular}{|l|l|l|l|l|}
\hline $\begin{array}{l}\text { Infrastructure } \\
\text { Preparation }\end{array}$ & 5 days & & & \\
\hline Training & & 3 days & & \\
\hline Implementation & & & $\begin{array}{l}\text { When there } \\
\text { is a new } \\
\text { staff / } \\
\text { rotation }\end{array}$ & \\
\hline $\begin{array}{l}\text { Further } \\
\text { Development }\end{array}$ & & & & 9 months \\
\hline
\end{tabular}

According to Almaiah and Al Mulhem [16], the success factors of e-learning implementation are awareness. The awareness of the staff and the stakeholder is a critical factor because it can help the process for e-learning. To raise awareness of e-learning, the role of stakeholders will play a big part. The instruction from the middle and top management in the form of instruction can be considered as the best way to give an understanding of the importance of e-learning. Explanation about the awareness in the meeting session can improve the awareness of the staff and the stakeholder. According to Uppal, Ali, and Gulliver [17], the content and the website to access e-learning must be taken into consideration because it is the first step to determine whether e-learning is good enough for the employee. The content is the main focus in e-learning development, whether it is meet the stakeholder objective or not. 
The acceptance of the e-learning designed in this study needs to be further investigated. User acceptance is an important part of knowing whether the designed e-learning is accepted or rejected [18]. It is important to know the user satisfaction to know the value of the e-learning [19][20]

\section{CONCLUSION}

The purpose of this research is to develop the e-learning content for the best practice of shelving activity for the research organization by using the SECI Method. SECI is used as a tool to gain knowledge, and after the knowledge is gain, the e-learning content is design using ADDIE. Knowledge in the form of best practice is obtained as content in e-learning.

The SECI method converts the staff knowledge of tacit knowledge into explicit knowledge so that others can use the knowledge. The knowledge that is gathered from the SECI method is converted into best practice for e-learning content. The best practice document contains the flow diagram for doing the shelving activity. The respondent from this research is two staff that is experienced in shelving activity. The result of this research is the best practices of shelving activity that is used as a material in designing e-Learning content.

When implementing e-learning it is needed to measure the achievement of the employee of using e-learning to make sure the e-learning is used for the learning process. According to Mehta, Morris, Swinnerton, and Homer [21], the low achievement of e-learning can result in the low adoption of e-learning. Therefore it is needed to measure the achievement of each employee.

\section{REFERENCES}

[1] H. Syam, M. Basri, A. Abduh, A. A. Patak, and Rosmaladewi, "Hybrid e-learning in Industrial Revolution 4.0 for Indonesia higher education," Int. J. Adv. Sci. Eng. Inf. Technol., vol. 9, no. 4, pp. 1183-1189, 2019.

[2] P. A. Mahatmavidya, R. P. Soesanto, A. Kurniawati, and L. Andrawina, "Characteristic and Competency Measurement Instrument Development for Maintenance Staff of Mechanical Expertise with SECI Method: A Case of Manufacturing Company," IOP Conf. Ser. Mater. Sci. Eng., vol. 319, no. 1, 2018.

[3] Agisni, R. P. Soesanto, A. Kurniawati, N. Ambarsari, and L. Andrawina, "Competency Measurement Instrument Design for Maintenance Staff of Electronic Expertise with SECI Method," in IOP Conference Series: Materials Science and Engineering, 2019, vol. 528 , no. 1 .

[4] D. Piriyadharshini and M. Dorairajan, "Innovative and Best Practices in Library and Information Services," Int. J. Sci. Humanit., vol. 3, pp. 7-12, 2017.
[5] S. Mulyani, "Pusat Pengembangan Koleksi dan Pengolahan Bahan Pustaka," 2015. [Online]. Available: http://pusbangkol. perpusnas. go.id/ files/Pengolahan Bahan Pustaka.pdf. [Accessed: 12-Jan-2020].

[6] C. Clark and R. E. Mayer, E-learning, and the science of instruction. Proven guidelines for consumers and designers of multimedia learning. John Wiley \& Sons, 2016.

[7] M. L. Farnese, B. Barbieri, A. Chirumbolo, and G. Patriotta, "Managing Knowledge in Organizations: A Nonaka's SECI Model Operationalization," Frontiers in Psychology, vol. 10. p. 2730, 2019.

[8] A. Muhammad Idkhan, Djuanda, and I. I. Putra, "Implementation of mechanical technology competence learning model with maximum likelihood estimation," Int. J. Adv. Sci. Eng. Inf. Technol., vol. 9, no. 5, pp. 1535-1543, 2019.

[9] R. Kraleva, M. Sabani, and V. Kralev, "An analysis of some learning management systems," Int. J. Adv. Sci. Eng. Inf. Technol., vol. 9, no. 4, pp. 1190-1198, 2019.

[10] I. Nonaka and H. Takeuchi, "Knowledge-Creating Company," Knowledge-Creating Co., 1995.

[11] R. P. Soesanto, M. S. Utama, and A. Kurniawati, "Pengukuran Kualitas Sistem Informasi Manajemen Laboratorium," no. November, 2013.

[12] I. Komninou, "A Case Study of the Implementation of Social Models of Teaching in e-Learning: 'The Social Networks in Education', Online Course of the Inter-Orthodox Centre of the Church of Greece," TechTrends, vol. 62, pp. 146-151, 2018.

[13] S. R. Patel, P. J. Margolies, N. H. Covell, C. Lipscomb, and L. B. Dixon, "Using Instructional Design, Analyze,Design, Develop, Implement, and Evaluate, to Develop e-Learning Modules to Disseminate Supported Employment for Community Behavioral Health Treatment Programs in New York State," Curriculum, Instr. Pedagog., vol. 6, 2018.

[14] M. Mayfield, "Creating training and development programs: using the ADDIE method," Dev. Learn., pp. 19-22, 2011.

[15] E. Garbani-Nerini, N. Kalbaska, and L. Cantoni, "Evaluating the Development and Impact of an eLearning Platform: The Case of the Switzerland Travel Academy," in Information and Communication Technologiesin Tourism 2018, 2018.

[16] M. A. Almaiah and A. AL Mulhem, "Conceptual framework for determining the success factors of e-learning system implementation using Delphi technique," J. Theor. Appl. Inf. Technol., vol. 96, no. 17, pp. 5962-5976, 2018.

[17] M. A. Uppal, S. Ali, and S. R. Gulliver, "Factors determining elearning service quality," Br. J. Educ. Technol., vol. 49, no. 3, pp. 412-426, 2018.

[18] Ramadiani, Azainil, U. Haryaka, F. Agus, and A. H. Kridalaksana, "User Satisfaction Model for e-Learning Using Smartphone," Procedia Comput. Sci., vol. 116, pp. 373-380, 2017.

[19] R. D. Freeze, K. a Alshare, P. L. Lane, and H. Joseph Wen, "IS success model in e-learning context based on students' perceptions," J. Inf. Syst. Educ., vol. 21, no. 2, p. 173, 2010.

[20] A. Hayashi, C. Chen, T. Ryan, and J. Wu, "The Role of Social Presence and Moderating Role of Computer Self Efficacy in Predicting the Continuance Usage of E-Learning Systems," J. Inf. Syst. Educ. 15(2), vol. 15, no. 2, pp. 139-154, 2004.

[21] A. Mehta, N. P. Morris, B. Swinnerton, and M. Homer, "The Influence of Values on E-learning Adoption," Comput. Educ., vol. 141 , p. $103617,2019$. 